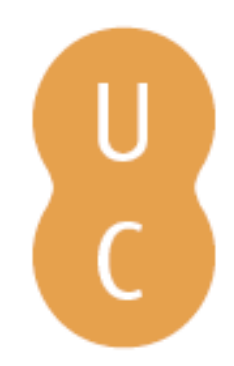

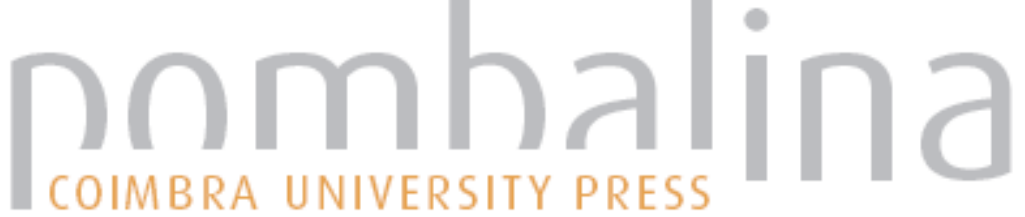

A new anomodont taxon from the mozambican Karoo (Niassa province, late permian)

Autor(es): $\quad$ Araújo, R.; Castanhinha, R.; Junior, L. C.

Publicado por: Imprensa da Universidade de Coimbra

URL

persistente: URI:http://hdl.handle.net/10316.2/31406

DOI: $\quad$ DOI:http://dx.doi.org/10.14195/978-989-26-0534-0_14

Accessed : $\quad$ 26-Apr-2023 15:57:42

A navegação consulta e descarregamento dos títulos inseridos nas Bibliotecas Digitais UC Digitalis, UC Pombalina e UC Impactum, pressupõem a aceitação plena e sem reservas dos Termos e Condições de Uso destas Bibliotecas Digitais, disponíveis em https://digitalis.uc.pt/pt-pt/termos.

Conforme exposto nos referidos Termos e Condições de Uso, o descarregamento de títulos de acesso restrito requer uma licença válida de autorização devendo o utilizador aceder ao(s) documento(s) a partir de um endereço de IP da instituição detentora da supramencionada licença.

Ao utilizador é apenas permitido o descarregamento para uso pessoal, pelo que o emprego do(s) título(s) descarregado(s) para outro fim, designadamente comercial, carece de autorização do respetivo autor ou editor da obra.

Na medida em que todas as obras da UC Digitalis se encontram protegidas pelo Código do Direito de Autor e Direitos Conexos e demais legislação aplicável, toda a cópia, parcial ou total, deste documento, nos casos em que é legalmente admitida, deverá conter ou fazer-se acompanhar por este aviso. 



\title{
A NEW ANOMODONT TAXON FROM THE MOZAMBICAN KAROO (NIASSA PROVINCE, LATE PERMIAN)
}

\author{
UM NOVO TÁXONE DO KAROO MOÇAMBICANO \\ (PROVÍNCIA DO NIASSA, PÉRMICO SUPERIOR)
}

R. Araújo ${ }^{1,2, *}$, R. Castanhinha ${ }^{2,3, *}$ e L. C. Junior ${ }^{4, *}$

\begin{abstract}
The Metangula Graben (Mozambique), after nearly half a century of scarce collecting, is now providing new dicynodont specimens that will increase knowledge of Karoo basins outside South Africa. Based on a complete ilium we report the initial results from our expedition with a new dicynodont taxon occurrence for the Mozambican Karoo: aff. Diictodon. We also relocate the fossil site with precise geographic information. Allocation to aff. Diictodon is based upon the reduced development of the preacetabular process, modest development of the supracetabular buttress, and presence of a robust neck. Morphological dissimilarities and the variation of the ilia within Diictodon does not allow us further taxonomic refinement. This specimen was recovered from the analogous South African Tropidostoma Zone and, represents the first African Diictodon feliceps outside South Africa and Zambia, reinforcing the cosmopolitan nature of this taxon.
\end{abstract}

Keywords - aff. Diictodon; Tatarian; Mozambique; Niassa

Resumo -O Graben de Metangula (Moçambique), após quase meio século de recolhas escassas, fornece agora novos espécimes de Therapsida que aumentam o conhecimento das bacias do Karoo. Baseado num ílio completo, relatamos os resultados iniciais de uma expedição prévia com uma nova ocorrência de um táxone de Anomodontia para o Karoo

1 Roy M. Huffington Department of Earth Sciences, Southern Methodist University, PO Box 750395 , Dallas, Texas, 75275-0395.

2 Museu da Lourinhã, Rua João Luis de Moura, 95, 2530-158 Lourinhã, Portugal.

3 Instituto Gulbenkian de Ciência, Rua da Quinta Grande, 6P-2780-156 Oeiras, Organogenesis Ibn Batuta (A1) - Room 1A, Portugal.

4 Museu Nacional de Geologia, Av. 24 de Julho, 355, Maputo, Mozambique.

* These authors contributed equally to this work. 
Moçambique: aff. Diictodon. Também relocalizámos a jazida de fósseis e fornecemos informaçóes geográficas precisas. A atribuição aff. Diictodon baseia-se em: desenvolvimento reduzido do processo pré-acetabular, desenvolvimento modesto do processo supracetabular, e presença de uma constriçấo robusta. Dissimilaridades morfológicas e variação dos ílios nos Diictodon não nos permitem um maior refinamento taxonómico. Este espécime foi colhido nos estratos análogos à Zona de Tropidostoma Sul-Africana, e representa o primeiro Diictodon fora da África do Sul e Zâmbia, reforçando o carácter cosmopolita deste táxone.

Palavras-chave - aff. Diictodon; Tatariano; Moçambique; Niassa

\section{1 - Introduction}

In July 2009 a preliminary expedition to the Metangula Graben (Niassa Province) was successful; the expedition not only rediscovered important fossil sites but have also shown that all sites pinpointed are very productive and are far from being well studied.

This is a preliminary account that provides new insights in the largely unexplored basin of the Mozambique Karoo, apparently bearing a wider taxonomic diversity than previously thought (Fig. 1). The faunal list from the Mozambican Karoo is far from being complete and future systematical sampling is required, accompanying the efforts being currently made in adjacent Karoo basins (SIDOR et al. 2010a; SIDOR et al. 2010b). The main purposes of this paper are to relocate the fossil locality that was vaguely indicated in the literature and identify the taxonomic affinities of an ilium recovered in 2009 from this basin.

Discoveries, regarding synapsids in the Metangula Graben, began when M. Domingos Rocha, who was part of a geological mapping project, led by A. Borges (Geological and Mines Services) and collected the first synapsid remains from Mozambique in 1949. This early mapping in search of coal and other natural resources provided a basis for understanding the geology of the region and a preliminary glance of the vertebrate fossils found there. The 1949 and 1954 fossil collections were sent to S. H. Haughton in South Africa, who wrote a preliminary note on the material and briefly referred to it in a broader article (HAUGHTON, 1963). This collection, now deposited in the Bernard Price Institute, was partially studied by LATIMER et al. (1995), who identified tooth replacement patterns in Endothiodon sp. The 1961 collection was studied by ANTUNES (1975), who described skull elements of Endothiodon and an unidentified gorgonopsian. BORGES et al. (1953), characterized the geological sequence of the lower portion of the basin as the "Lunho Series," which was later correlated with the South African Tropidostoma Assemblage Zone (TEIXEIRA \& GONÇALVES, 1959; ANTUNES, 1975); late Permian (sensu RUBIDGE et al., 1995).

A second wave of geological exploration was done by the Direcção Nacional de Geologia, led by J. Verniers from 1977 to 1980. The four year project resulted in a detailed knowledge of the stratigraphy and economical potential of the basin (VERNIERS et al., 1989), however without any significant insights on the vertebrate paleontology. 


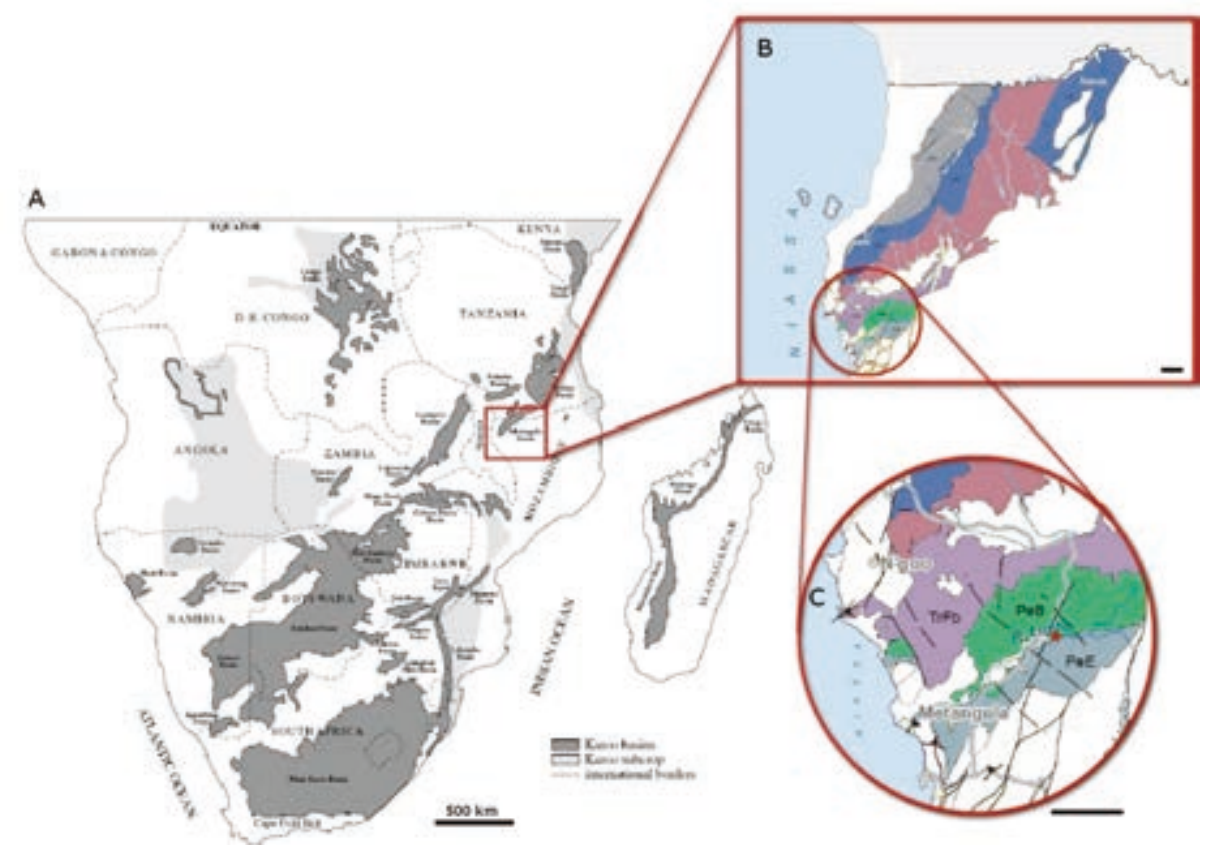

Fig. 1 - Maps showing the location of the findings. A - The Karoo basins in Southern Africa (modified from CATUNEANU et al., 2005). B - Map showing Niassa Province (Mozambique) with the Karoo outcrops highlighted with colors. C - Location of the ilium ML1612 (red star, 12 31' S, 34 57’ E).

Jrlp, Jurassic (Lupilichi Formation); JrTe, Jurassic (Tende formation); TrMe Triassic (Mecondéce Formation); TrFb Triassic (Fabuè Formation); PeB Permian (Beaufort Group, Cádzi formation); PeE Permian (Ecca Group, Matinde/Moatize Formation). Scale bars B and C equal to $10 \mathrm{~km}$.

\section{2- Geology and location}

The fossiliferous unit is located near Tulo, a small village extending along Metangula-Cóbue road. Tulo is located in the Lago District, Province of Niassa. The location referred by ANTUNES (1975) and VERNIERS et al. (1989) may be misleading, because the most productive sites occur on the north margin of the Tulo River and not between Lunho and Lundo rivers. The Karoo in Mozambique belongs, in a broad scale, to the Eastern Rift Basins group (CATUNEANU et al., 2005), which were unaffected by compressional flexural tectonics as the South African Karoo basin was. The Karoo outcrops in a graben that extends NE-SW which is enclosed in a Precambrian basement. The layer is equivalent to L10 from the BORGES et al. (1953) "Lunho series" and equivalent to K6 division from VERNIERS et al. (1989). The fossil bed is composed of a grey mudstone with abundant septaria-like calcareous concretions (VERNIERS et al., 1989). The K6 division is underlain by reddish to grey siltstone (K5), and overlaid by coarse sandstone intercalated by a siltstone layer (Mount Lilonga Formation). Although the K6 division in 
the Metangula Graben does not continue towards Tanzania, most of the so called Upper Karoo does, namely KSc and KSe (VERNIERS et al., 1989). Indeed the fossiliferous "Chiweta Beds" from Malawi as well as the Usili Formation from Tanzania are correlatable to the K6 division from Mozambique (CATUNEANU et al., 2005). According to ANTUNES (1975) the fossiliferous layer can be correlated to the Endothiodon Zone, which is according to the recent nomenclature equivalent to the Tropidostoma Zone by RUBIDGE (1995).

\section{3 - Systematic paleontology}

THERAPSIDA (BROOM, 1905)

DICYNODONTIA (OWEN, 1859)

aff. Diictodon (OWEN, 1876)

\section{4 - Description}

The ilium is nearly complete, only the periosteum around the dorsal edge is missing. In medial view, there is a crack that transverses the anterior and posterior edges from one side to the other of the neck. The lateral surface is concave whereas the medial one is flat. The ilium is longer than high which is indicative of the wide iliac blade, even taking into consideration the pre-and postacetabular processes. The medial side of the ilium is completely flat but the medial side tapers dorsally from the bulky acetabular region to the constantly thick iliac blade. The medial side bears four facets for the sacral ribs, which are evident by dorsoventrally-oriented depressions marked by striations along the same direction. The dorsal edge is slightly notched, differing substantially from the more extreme condition in Lystrosaurus. The dorsal edge is a smooth curve dorsally that descends abruptly until the postacetabular process. The slightly thickened anterior edge has a much wider curve than the posterior edge, which altogether forms the iliac neck. The iliac neck has a constriction index (IN/IB) of 0.74. Interestingly (see discussion), the posterior edge forms an obtuse angle. The postacetabular process is reduced forming only a small projection that nearly makes a right angle. The preacetabular process (IA) is larger than the postacetabular process (IP). It is hard to determine the areas of origin of the iliofibularis and iliotibialis due to lack of preservation of the periosteum.

More ventrally, the rounded supracetabular buttress is excavated posteriorly by the postacetabular notch that is not particularly deep in ML1612 (Fig. 2) (table 1). In fact, in ventral view the lateral slope of the supracetabular buttress and the iliofemuralis origination surface form an obtuse angle, contrary to the condition seen in Lystrosaurus. The acetabulum is deeply excavated; however the ilium seems only to participate with the more dorsal region to form the acetabulofemural articulation. Most of the acetabulum is located on the anterior side of the ventral part of the ilium. In ventral view the facets for the ischium and pubis are distinct by a kink in the ventral border. The flat facet for the ischium is larger $(3.0 \times 1.5 \mathrm{~cm})$ than the slightly convex facet for the pubis $(1.8 \mathrm{x} 0.9 \mathrm{~cm})$. 

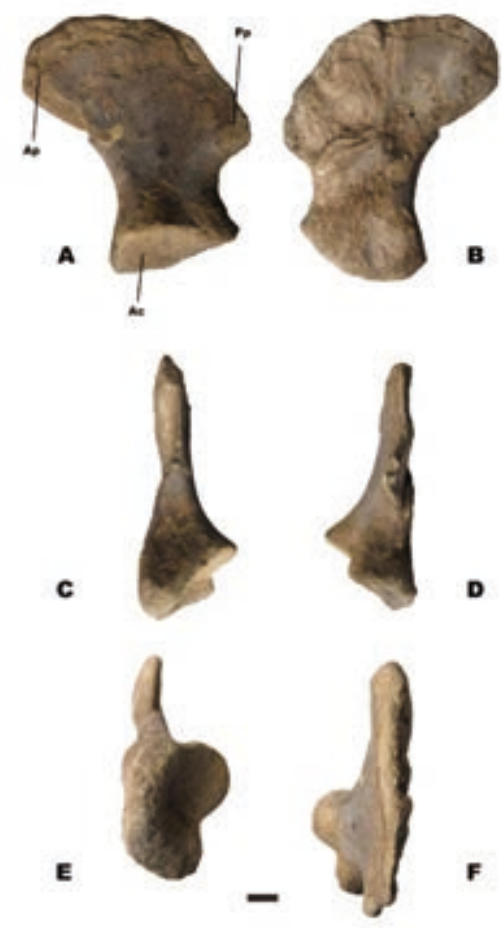

Fig. 2 - Left ilium (ML1612) in different views: A-Lateral; B-Medial; C-Anterior; D-Posterior; E-Ventral; F-Dorsal. Ac-Acetabulum; Ap-Anterior process; Pp-Posterior process. Scale bar $1 \mathrm{~cm}$.

\section{5 - Measurements}

Table 1 - Standardized measurements from RAY \& CHINSAMY (1990). Measurements in centimeters.

\begin{tabular}{lc} 
& ML1612 \\
\hline Preacetabular iliac process (IA) & 2.2 \\
Anteroposterior length of ilium (IL) & 5.8 \\
Postacetabular iliac process (IP) & 1.2 \\
Width of iliac base (IB) & 4.3 \\
Width of iliac neck (IN) & 3.2 \\
Iliac height (IH) & 6.8 \\
IA/IL & 0.38 \\
IP/IL & 0.21 \\
IL/IH & 0.85 \\
\hline
\end{tabular}




\section{6 - Identification and comparison}

Our comparison will be based essentially with tatarian dicynodonts but, when necessary, other taxa will also be analyzed.

The ilium can be differentiated from Cistecephalus on the basis of a more acute angle on the posterior border of the neck, as well as on the number of sacral vertebrae facets, only three in this species (CLUVER, 1978). However, the iliac blade, especially the anterior portion, shows some resemblances with BPI4086, in what concerns the development of the preacetabular process and the angles between the dorsal and anterior margins, but the abovementioned differences exclude a Cistecephalus ascription. Tropidostoma (SAMPK-K9960 in SURKOV et al. 2005) does not have a postacetabular process excluding a potential ascription of ML1612 to this genus. The preacetabular process of Robertia (KING 1981) is slightly short relative to the total length of the iliac blade compared to ML1612 (RAY \& CHINSAMY, 1990), whereas Rhinocynodon (SURKOV, 1998) bears the opposite condition. Furthermore, the neck of Robertiais is narrower relative to the total length of the iliac blade - 25\% from fig. 10 in KING (1981) vs. 44\% in ML 1612. Lystrosaurus postacetabular notch is considerably deeper and the supracetabular buttress even detaches from the ilium body (SURKOV et al., 2005); such condition is absent in ML1612. Considering the morphological description above, ML1612 closely resembles Diictodon feliceps, namely on the following aspects: reduced development of the preacetabular process to the total length of the ilium (RAY \& CHINSAMY, 1990), modest development of the supracetabular buttress, presence of a robust neck. Nevertheless, by analyzing the published data (DEFAUW, 1986; RAY \& CHINSAMY, 1990), all these features are still widely variable from specimen to specimen within the species Diictodon feliceps. Thus, only based on ilia, no true autapomorphies can be used to unambiguously ascribe ML1612 to this species.

Expectedly, ilia are hardly informative in phylogeny reconstruction among basal Anomodontia (e.g. ANGIELCZYK \& KURKIN, 2003; FRÖBISCH, 2007). In this case it makes apomorphy-based taxonomic identification particularly difficult. ANGIELCZYK (2007) uses the length of the iliac processes relative to the total length of ilium as characters to reconstruct the phylogeny of dicynodonts. The following characters are either derived from direct comparison of specimens or resulting from unused characters derived from the literature.

The fact that ML1612 presents four facets in the medial side corresponding to the ribs from four sacral vertebrae is important to the identification, since this trait was only confirmed until now in Kingoria, Endothiodon and Diictiodon (ANGIELCZYK \& KURKIN, 2003). Notably, as dissimilar features in Diictodon and Pristerodon, the posterior border forming the neck forms a much more acute angle in comparison with ML1612. Diictodon and Pristerodon are very alike in overall shape and dimensions: the postacetabular length and anteroposterior length of the ilium ratio in ML1612 (0.21) is in the range of Diictodon feliceps (0.12-0.34) and is close to Pristerodon (0.20). But, interestingly, ML1612 differs significantly in one aspect from all other dicynodon species: the ilium is longer than high (RAY \& CHINSAMY, 1990). This difference may be due to the later ontogenetic stage of ML1612, since this individual is considerably longer $(5.8 \mathrm{~cm})$ than the longest Diictodon feliceps ilium already described (SAM-PK-K6716a measuring $4.8 \mathrm{~cm}$ long, RAY \& CHINSAMY, 1990). However, ML1612 very apparent difference from Pristerodon lies on 
the construction of the acetabular region. Whereas Pristerodon the supracetabular region forms a well defined notch, in Diictodon feliceps and ML1612 the supracetabular buttress is modestly developed with a sinuous contour of the dorsal edge of the acetabulum.

The fact that the tatarian Diictodon feliceps is penecontemporaraneous to the strata in Mozambique, namely K6 division, is merely indicative that ML1612 can be ascribed to Diictodon feliceps. In the other hand, the morphological analysis above mentioned, forces us to go no further than aff. Diictodon.

The presence of aff. Diictodon in Mozambique adds a new spot on the map on an entirely different basin, reinforcing the view that this genus may be cosmopolitan (ANGIELCZYK \& SULLIVAN, 2008). This genus has only been reported for Zambia (ANGIELCZYK \& SULLIVAN, 2003), South Africa and China (SUN, 1973).

\section{Acknowledgements}

The PalNiassa project counted with the help of many people who either aided us in the field, logistically, financially, or scientifically. Among all those people we are particularly thankful to: Adelaide Pedro (Direcção Nacional de Geologia de Tete), Adriano Sênvano (Direcção Nacional de Geologia de Moçambique), Álvaro Henriques, Anastácio Tamele (GED), Ângelo Cumbe (MNG), Ângelo Madrugas (GED), Dale Winkler (SMU), Daúd Jamal (UEM), Eva Lança, Fernando Nogal (ML), Hernâni Mergulhão (ML), João Mugabe (UEM), Lopo Vasconcelos (UEM), Louis L. Jacobs (SMU), Lucília Chuquela (MHN, Maputo), Luís Macuango (régulo in Tulo), Maria Matos (ML), Miguel Telles Antunes (Academia de Ciências de Lisboa, ML), Octávio Mateus (UNL, ML), Paulo Zucula (Minister of Transports of Mozambique) and Queen of Muchenga. We also thank Dale Winkler and Kenneth Angielczyk who have made pertinent comments on versions of this manuscript.

\section{References}

ANGIELCZYK, K. D. \& KURKIN, A. A. (2003) - Phylogenetic analysis of Russian Permian dicynodonts (Therapsida: Anomodontia): implications for Permianbiostratigraphy and Pangaean biogeography. Zoological Journal of the Linnean Society,139, p. 157-212.

ANGIELCZYK, K. D. \& SULLIVAN, C. (2003) - Diictodon feliceps (Owen, 1876), a dicynodont (therapsida, anomodontia) species with a pangaean distribution. Journal of Vertebrate Paleontology, 28, p. 788-802.

ANGIELCZYK, K. D. \& SULLIVAN, C. (2008) - Diictodon feliceps (Owen, 1876), a dicynodont (Therapsida, Anomodontia) species with a Pangaean distribution. Journal of Vertebrate Paleontology 28, p. 788-802.

ANGIELCZYK, K. D. (2007) - New specimens of the tanzanian dicynodont “Cryptocynodon parringtoni” von Huene, 1942 (Therapsida, Anomodontia), with an expanded analysis of Permian dicynodont phylogeny. Journal of Vertebrate Paleontology, 27, p. 116-131.

ANTUNES, M. T. (1975) - Sur quelques reptiles du Karroo de Maniamba, Mocambique. Colloque international CNRS, Paris, 218, p. 371-380.

BORGES, A., NUNES, A. \& FREITAS, F. (1953) - Contribuição para o reconhecimento do Karroo Português do Lago Niassa. Província de Moçambique, Serviços de Industria e Geologia, Série de Geologia e Minas, Memorias e Comunicaçōes, 12, p. 1-15. 
BROOM, R. (1905) - On the use of the term Anomodontia. Records of the Albany Museum, 1, p. 266-269.

CATUNEANU, O., WOPFER, H., ERICKSON, P. G., CAIRNCROSS, B., RUBIDGE, B. S., SMITH, R. M. N. \& HANCOX, P.J. (2005) - The Karoo basins of South-Central Africa. Journal of African Earth Sciences, 43, p. 211-253.

CLUVER, M. A. (1978) - The skeleton of the mammal-like reptile Cistecephaluswith evidence for a fossorial mode of life. Annals of the South African Museum, 76, p. 213-246.

DEFAUW, S. L. (1986) - The Appendicular Skeleton of African Dicynodonts. Unpublished Ph.D. dissertation, Wayne State University, Detroit, Michigan, 248 p.

FRÖBISCH, J. (2007) - The cranial anatomy of Kombuisia frerensis Hotton (Synapsida, Dicynodontia) and a new phylogeny of anomodont therapsids. Zoological Journal of the Linnean Society, 150, p. 117-144.

HAUGHTON, S. H. (1963) - Note on the distribution of fossil Reptilia of Karroo Age. Palaeontologia Africana, 8, p. 1-37.

KING, G. M. (1981) - Postcranial skeleton Robertia broomiana, an early dicynodont (Reptilia: Therapsida) from the South African Karoo. Annals of the south african museum, 84(5): 203-231.

LATIMER, E. M., GOW, C. E., \& RUBIDGE, B. S. (1995) - Dentition and feeding niche of Endothiodon (Synapsida; Anomodontia). Palaeontologia Africana, 32, p. 75-82.

OWEN, R. (1859) - On the orders of fossil and recent Reptilia and their distribution in time. Reports of the British Association for the Advancement of Science, p. 153-166.

OWEN, R. (1876)-Descriptive and Illustrated Catalogue of the Fossil Reptilia of South Africa in the Collections of the British Museum. Taylor and Francis, London, 88pp.

RAY S. \& CHINSAMY A. (1990) - Functional aspects postcranial anatomy Permian dicynodon Diictodon ecological implications. Palaeontology, 46, p. 151-183.

RUBIDGE, B. S. (1995) - Biostratigraphy of the Beaufort Group (Karoo Supergroup). South African Committee for Stratigraphy Biostratigraphic Series, 1, p. 1-46.

SIDOR, C. A., ANGIELCZYK, K. D., WEIDE, D. M., SMITH, R. H., NESBITT, S. J. \& TSUJI, L. A. (2010a) - Tetrapod fauna of the lowermost Usili formation (Songea Group, Ruhuhu Basin) of southern Tanzania, with a new burnetiid record. Journal of Vertebrate Paleontology, 30, p. 696-703.

SIDOR, C., STEYER, J., ANGIELCZYK, K., SMITH, R. \& TOLAN, S. (2010b) - New information on the Permian and Triassic vertebrate faunas of the Luangwa basin, Zambia. Journal of Vertebrate Paleontology, 30 (3 supplement): 165A.

SUN, A.-L. (1973) - A new species of Dicynodon from Sinkiang. Vertebrata Palasiatica, 11, p. 52-58.

SURKOV, M. V. (1998) - The Postcranial Skeleton of Rhinodicynodon gracile Kalandadze, 1970 (Dicynodontia). Paleontological Journal, 32, p. 402-409.

SURKOV, M. V., KALANDADZE, N. N., \& BENTON, M. J. (2005) - Lystrosaurus georgi, a dicynodont from the Lower Triassic of Russia. Journal of Vertebrate Paleontology, 25, p. 402-413.

TEIXEIRA, C., \& GONÇALVES, F. (1959) - Contribuição para o conhecimento geológico do Karroo da Africa Portuguesa IV. Descrição de alguns restos de vegetais fósseis do Karroo das regiōes do Niassa e de Mossurize (Moçambique). Garcia de Orta, 7, p. 785-789.

VERNIERS, J., JOURDAN, P. P., PAUliS, R. V., FRASCA-SPADA, L. \& DE BOCK, F. R. (1989) - The Karroo Graben of Metangula, Northern Mozambique. Journal of African Earth Sciences, 9, p. 137-158. 